\title{
Communication Building between Islamic Boarding School in Surakarta: A De-radicalization Strategy
}

\author{
Burhanuddin Auzai; Pawito; Andrik Purwasito \\ Communication Science, Postgraduate Sebelas Maret University of Surakarta, Indonesia
}

http://dx.doi.org/10.18415/ijmmu.v6i3.955

\begin{abstract}
The radical stigma among Islamic boarding schools still becomes a negative opinion among the people. This is reinforced by a press released by National Counter Terrorism Agency, called BNPT, in which there are nineteen Islamic boarding schools indicated radicalism in Indonesia. For this reason, deradicalization needs to be applied. Based on the problem, this research aimed at finding out how to deradicalize among Islamic boarding schools. This was a kind of qualitative research using an in-depth interview to collect the data. The research was conducted in Al-Muayyad Boarding School, Assalam Boarding School, and Al-Mukmin Boarding School. The findings revealed that Al-Muayyad Boarding School had communication between leaders and Islamic boarding schools, and also there was the spirit of maintaining unity. From Assalam Boarding School, it revealed that it implemented the curriculum of the religious department and work a lot by writing ideas about radicalism in the media. While the representative of Al-Mukmin explained that there were many discussions with individuals or groups that were considered radical, increasing the source of reference so that not to believe in only one media but must compare to other media.
\end{abstract}

Keywords: Communication Building; Radicalism and Deradicalization; Islamic Boarding School

\section{Introduction}

Indonesia for the past fifteen years has been a victim of terrorist attacks such as suicide bombings. The suicide bombing started from Bali Bombings on October 12, 2002, at night. The bomb blast destroyed the Paddy's Pub and Sari Club (SC) buildings in Kuta and there was also an explosion that happened near the US Consulate office in Denpasar. The next incidents were JW Mariott Bombings occurring on August 5, 2013, and the Kampung Melayu Bombings began with an exploding suicide bombing in Kampung Melayu Terminal, East Jakarta, April 25, 2017. Furthermore, the latest was Surabaya Bombings occurred on May 13, 2018, that was carried out by a group Anshorut Daulah Jamaah.

All the bombers, from the results of the crime scene carried out by the police, were found always having the identity of Islam. Based on this case, Muslims are always associated with radicalism, especially Islamic boarding schools. It is reinforced by the results of offender profiling issued by the BNPT that nineteen Islamic boarding schools in Indonesia are indicated teaching doctrines that contain radicalism. 
Head of BNPT, Saut Isman Nasution, said that based on the results of offender profiling there were nineteen Islamic boarding schools indicated to teach doctrines of radicalism. The nineteen Islamic boarding schools are Al-Muaddib Islamic Boarding School, Cilacap; Al-Ikhlas Islamic Boarding School, Lamongan; Nurul Bayan Islamic Boarding School, North Lombok; Al-Ansar Islamic Boarding School, Ambon; Wahdah Islamiyah Islamic Boarding School, Makassar; Darul Aman Islamic Boarding School, Makassar; Amanah Islamic Boarding School, Poso; Central Islamic Mission Boarding School, North Jakarta; Al-Muttaqin Islamic Boarding School, Cirebon; Islamic Boarding School Nurul Islam, Ciamis; and several other Islamic boarding schools in Aceh, Solo and Serang.

Persyarikatan Muhammadiyah through the general chairman of the Muhammadiyah Central Executive Haedar Nashir argued that whatever the motives for the shake of religious beliefs or defending certain groups, radicalism is problematic. Quoted from the news page (sangpencerah.com). In the life of a society or nation, radicalism will always be a problem. Moreover, radicalism in the form of violence, such as physical conflict, terror or terrorism, and open war is an act that harms the life of the nation. Radicalism remains problematic regardless of reasons and motives, including the encouragement of religious beliefs or defending certain understandings. This because of social conflict, terrorism, and history of war has always been a social trauma that is always remembered and heartbreaking in the lives of humankind.

The invitation to fight radicalism was also conveyed by the General Chair of the Indonesian Ulema Council, called MUI, KH. Ma'ruf Amin asserted that radical notions have distorted true religious values. Accordingly, he invites all components of the nation to fight radicalism. In this era that is easy to have internet access, Ma'ruf Amin considers the virtual world to be the most effective tool for radical groups to spread radicalism. His opinion on this context is an intensive effort to combat radicalization is indeed not easy, especially through cyberspace, it must be done together. It needs synergy from ulema and umara and all people must be involved.

The government issued a policy of deradicalization as a solution to the terrorist attacks that hit Indonesia. It can be noted that deradicalization is a national program published through BNPT in 2013. This is based on the Indonesian Derivatives Blueprint book issued by BNPT published on the national interest website nationalinterest.org former prisoners and the community.

In the context of research, deradicalization as communication needs contributions from Islamic boarding schools located in Surakarta and its surroundings. From several Islamic boarding schools that stand in Surakarta and around, the researchers took three Islamic boarding schools as research objects for particular reasons. The boarding schools are (1) Al-Muayyad Mangkuyudan Islamic Boarding School or often called Al Muayyad, (2) Assalam Islamic Modern Boarding School (called PPMI Assalam), (3) AlMukmin Ngruki Islamic Boarding School. Based on the background of this research, the author tries to find the messages of deradicalization among Al-Muayyad and PPMI Assalam Islamic boarding schools.

\section{Theoretical Review}

\section{Radicalism}

In Indonesia, according to Wahid Institute, radicalism is often associated with religious understanding although it can be derived from various fields such as the social, political economy and others. There is no similar pattern of radicalism movements in Indonesia since in one side there are those who struggle for the establishment of "Khilafah Islamiyah", but on another side there are those who struggle for the establishment of "an Islamic state of Indonesia" and also there are those who only fight for Islamic law without having to establish an "Islamic state". 
Based on online KBBI (official Indonesian dictionary) from the Ministry of Education and Culture, radicalism has the first definition as radical ideology or understanding in politics, second definition as ideology or understanding that want social or political change or renewal utilizing violence or drastic, the three extremes in political flow.

Another view about the radicalism phenomenon, according to Ahmad Suedy, which was published on the Gusdurian.net website, explained that religious radicalism happened not only in Indonesia but also in other countries both in developing and developed countries. Globalization and progress in information are the factors spreading religious radicalism. Differences in radicalism between one country and another have different ways to overcome them. In developed countries, the tradition of anti-violence and protection of victims is very strong and can be pushed to the maximum.

In Islam, radicalism movement or religious fundamentalism is identified as a movement (Hasyim Muhammad, 2015) that has general characteristics: a) Islamic movements that politically make Islam an ideology and culturally make the West as the others; b) have principles that lead to ideology resistance or oppotionalism; c) rejection of hermeneutics because the understanding of the Qur'an is merely scriptualistic; d) eptymologically, in the area of the socio-political movement of revivalism and meloka pluralism; e) reject historical and sociological developments, and view that all human activities in the world must adjust to the text of the Qur'an.

In agreement of this opinion, Purwasito explained the radicalism written on the page ndalempoerwahadiningratan.wordpress.com, Radicalism is involved in all religions, not only in Islam but also in Catholicism, Hinduism, Christianity, Buddhism. In the groups/ sects of belief, groups or organizations in society also have radicalism. Based on Purwasito's opinion, radicalism is the ideal ideology of teaching that wants to return to its roots (radix). It is also a movement that the initiators and followers want to manifest against the status-quo. Radicalism is purifying the idea to the roots conservatively (not by violence) and to others extremely (with violence).

Ideologically according to (Jainuri 2016, p. 5), radicalism is divided into two types. The first is non-compromise ideology relating to the acceptance of development, change and the concept of progress. This group is also commonly called the right radical. Whereas non-compromise ideology that is based on past values that do not want to accept change is called left radical. The second is radicalism which assesses very high dissatisfaction on the status quo and the desire for change quickly in extreme ways. Furthermore, it wants to make fundamental changes in society and leadership.

Radicalism in the history of Islam began in the Shiffin war in 657 AD namely the movement of the Khawarij from the army of Ali Bin Abi Talib. It is considered radical because it is based on the spirit of conservative religious understanding. Ali Bin Abi Talib, through his negotiator, Abu Musa Al-Asy'ari who received peace from the Mu'awiyah party through 'Amr bin 'Ash judged by the Khawarij as an act that deviated from the principles of Islamic teachings because it did not base on the provisions of Allah's law. The presumption of the Khawarij of those who do not follow Allah's law has committed a major sin. The basic understanding of the Khawarij is whoever determines something without being based on the law of Allah has committed a major sin, because it belongs to the group of Fasiq (someone who violates Islamic law), dhalim (unjust acts of exploitation, oppression, and wrongdoing) and kafir (non-believer).

\section{Deradicalization}

To overcome the radicalism, it needs to be de-radicalization. Deradicalization is a term often used to describe the process of change or change the views of people or society towards the world, from "extreme" society into normal society. The concept of deradicalization has become very important after finding several terrorism cases even though the perpetrators have been dealt with very firmly and 
violently actions. Punishing and cracking down on terrorists or radicals cannot stop it. On the contrary, terrorists can recruit new members including when they are in prison (Hasyim Muhammad, 2015, p. 202).

Another definition of deradicalization is an attempt to invite terrorists and their supporters to abandon acts of violence, such as public diplomacy efforts aimed at "winning hearts and minds" concluded from Mukodi (2015). Meanwhile, according to The International Center for the Study of Radicalization and Disengagement, it is the process of individuals or groups to stop their involvement in violent organizations or terrorist groups.

Whereas based on the oxford dictionaries, deradicalization is an action or process that causes an extreme, radical individual to take a more moderate position in social or political matters. Another definition from collins dictionary, deradicalization is action or practice to encourage individuals and groups with extreme and violent ideologies in religion or politics to adopt a more moderate view. In this study, deradicalization is an understanding to encourage Islamic boarding schools having extreme views in religion to adopt a more moderate view.

Whereas the deradicalization program based on BNPT view is for people who do not know and explore Islam in which they consider Islam as a religion filled with anger by the followers and committed acts of violence against followers of other religions or other different groups in understanding Islam. This happens because there are many shows that present news about the conditions of other countries that have been hit by the war of acts of terror committed by people in the name of "Islam". The followers of Islam and the groups of Islam are different. Different group of Islam will also understand Islam differently. The difference is due to a different interpretation of Islam. Based on this case, it needs to introduce true Islam to people who "want to know" about Islam.

If Islam is well introduced, rationally argued and politely shown, the people will understand Islam, the religion brought by Prophet Muhammad SAW. The more people understanding of Islam, the more people are interested in Islam. No wonder if there are people who initially hated Islam but later instead becomes Muslims. This happens because of the guidance of Allah SWT.

\section{Sources of Information on Radicalism and Deradicalization of Islamic Boarding Schools}

Information is an activity carried out and the use of channels by individuals (information seekers) after carrying out the process of identification of sources of information that have been obtained following the needs of information seekers. According to Wilson (1999: 251) information-seeking behavior arises as a consequence of the needs felt by users of the information to satisfy, make demands on sources of information or formal or informal services which can result in success or failure. In traditional thinking, when thinking about sources of information, it will lead to information sources in the form of print and electronics. In print sources, the mind will be focused on all reading material produced from ink and paper, such as books, newspapers, and magazines. The more advanced the development of information technology, the more print media both newspapers, magazines, books having transformation into another form without paper and ink. Whereas about electronic information sources, the mind will think about radio, television, recordings and the internet. As print media with increasingly sophisticated technological developments, changes in the landscape of the broad types of information sources will join into one in a large electronic network called the web.

Currently, two types of media that can be used as reference sources of information in information reference needs, namely print and electronic media. According to Joseph Turow, author of Media Today, print media and electronic media of An Introduction To Mass Communication are divided into several parts. Firstly, books, newspapers, and magazines are included in the print media while for electronic media such as radio, television and the internet. 


\section{Print Media}

\section{Book}

Books have many definitions. According to UNESCO (the United Nations Education, Scientific, and Cultural Organization) (in Turow, 2009), books are publication media printed having no period, having at least 49 pages thick including covers. Besides, there are five important parts used as differentiators between books and other media:

a) The book is printed, books are made from one or more printing machines from one or a group of writers or written in handwriting.

b) The book is a publication media, printed in numerous copies and circulated to the public.

c) The book consists of at least 49 pages according to the UNESCO version, intended to exclude short documents. While information sheets totaling under 49 pages are called pamphlets.

d) The book has a cover.

e) Books are not published periodically (periodically). That means the book is not updated with the same title regularly such as magazines and newspapers.

In this study, it can be related to how books are used as a source of reference information in Islamic boarding schools both in Al-Muayyad and Assalam. The books mean any book that is included as a reference in understanding radicalism as well as the media in delivering deradicalization messages in minimizing that view.

\section{Newspapers}

It is one of the print media products that is published regularly either weekly or daily and printed in a large number of copies. Newspapers have a long history in which the brief one refers to that definition before John Gutenberg invented the printing press in the mid-1400s. The existence of newspapers before the invention of the printing press could not be called a newspaper. Although in 59 AD Emperor Julius Caesar introduced a newspaper titled Acta Diurna, the invention of the printing press by Gutenberg did not immediately generate a large-scale newspaper publication. In England, newspapers were not produced until almost 1600s. The reason is the British empire was afraid of the newspaper. The kingdom considered the function of the newspaper to report events, provoke political discussion that leads to overthrow. Newspaper publishing in Europe was consumed by businessmen because of their demands to know what was happening politically and economically throughout Europe and in the "New World" which was the result of European colonies. In the late 1600s, when the British ruled the king was forced to form parliament made newspapers something normal in the country. In the current time, newspapers are not only published in print version but also published in an online form, for instance, Kompas newspaper has printed version "Koran Kompas" and online version on www.kompas.com.

\section{Magazine}

The origin of the magazine is derived from French which means storehouse. It can be explained simply that magazine is a collection of stories, poems, advertisements and others owned by the editor which is believed to attract readers' interests.

\section{Electronic Media}

\section{Radio}

Discussing the origin of the radio should refer back to the history of the nineteenth century. The aim of the radio was not for entertainment. In 1842, Samuel Morse developed the telegraph by finding the 
ways how the telegraph wire could send the messages through the air using electric waves or frequencies. In 1895, Gugkiemo Marconi from Italy was successful to develop ideas from Morse using point and line codes so that he managed to send messages further than using telegraph wire. Now, many radios function as communication media to entertain by providing music and news.

\section{Television}

The introduction of television commercials was first in America in 1946, right after World War II. But the idea of television had already existed for some time before that event and was published by Scientific American magazine in 1970. While in England in 1879 through the British humor magazine Punch was published a picture of a couple watching a long-distance tennis match through the screen. Three years later a French artist attracted a future family watching the war on the main screen.

Although the idea of television is in the air, the actuality of television broadcasting is to scan visual images and emit electronically, generally accompanied by sounds, and in the form of electromagnetic waves which when received can be converted into visual images. Research on the development of television technology continued in Germany in the 1880s and continued in the United States, Scotland, Russia and other countries over the next decade. In the United States, precisely in New York, the first television broadcasting program was about the drama that came from the General Electric studio experiment at Schenectady. So from the early history of the introduction of television, it can be concluded that television is a visual transmission of images that are generally accompanied by sound, formed by electromagnetic which can be converted back into visual images.

\section{Internet}

Internet firstly came from a private computer in the 1980s located in office and the house having video, keyboard microprocessing unit, and storage device (a was changed or "floppy", disk drive and permanent drive or hard drive). That kind of computer could not send the message to other computers. Later, the computer had the online capability which could digital information from everywhere through telephone. Hardware that can facilitate a computer online is a modem. The modem is a device applied in a computer to convert digital data to analog and then transmit the data to another modem.

The modem working system made the industry developed modems commercially and built online networks such as Prodigy and America Online. The services offered by the online network to consumers were online encyclopedias that help to offer homework and chatting with people who have similar interests. Therefore, in the mid-1990s these companies competed with a very large online network called the internet. From the history, it can be defined that the internet was originally a networked computer system in which the users could access the network from computer devices, then if they got permission from other computer device users, they could share the information and even talk to each other through network computer devices.

Based on the concept above, in this study communicators or scholars use any source references used as references in understanding the terms of radicalism in their circles and use any media to make deradicalization efforts that have been carried out starting from print media such as books, magazines and newspapers, electronic media, internet media or other media.

\section{Methodology}

This research was conducted in Surakarta and the surroundings with its various dynamics; known as the city of culture, the city of batik, and the city of liwet. The nuances of the Javanese culture is very strong in the city area. It is indicated by several things, some of which is the existence of Kasunanan and 
Mangkunegaran palaces, the courtesy and tolerance held by society, and cultural agendas such as grebeg suro and sekaten are still attached to Surakarta. Instead, the history also records Surakarta as the place of the birth of Sarekat Dagang Islam (SDI), a movement in Indonesia, which was considered as the background of the national movement against Dutch colonialism.

Meanwhile, the research was conducted at Al-Muayyad Islamic Boarding School, Assalam Islamic Modern Boarding School. These institutions were chosen for this current study for the following reasons:

1. Al-Muayyad Islamic Boarding School,

The first reason for choosing Al-Muayyad Islamic Boarding School is that this Islamic school is one of the oldest Quran Islamic school in Surakarta. This school was pioneered by K.H Abdul Mannan together with K.H Ahmad Shofawi and Prof, K.H Moh Adnan in 1930. And then the school system was arranged into the madrasa system by K.H Umar Abdul Manan in 1937. Further, the madrasa system was supplemented by Diniyyah Madrasa (1939), in 1970 it was followed by the establishment of MTs and SMP, after four years, an SMA (1974) was established. And the last, in 1992, it was completed with a high school in an Islamic boarding house. This Islamic school represents the traditional Islamic circles or if it is associated with Islamic organizations, it is close to Nahdhatul Ulama.

\section{Assalam Islamic Modern Boarding School}

This is a private Islamic educational institution which is under the auspices of the Surakarta Islamic Education Board Foundation, called YMPI, founded by (late) H. Abdullah Marzuki and Hj. Siti Aminah Abdullah on 17th Shawwal $1402 \mathrm{H}$ to coincide with the 7th August 1982 at Jalan Yosodipuro No 56 Punggawan Surakarta with an area of 2,845 m, as a donation from (late) H. Abdullah Marzuki and $\mathrm{Hj}$. Siti Aminah Abdullah, the owners of the printing industry of PT. Three Musketeers. The image built by Assalam is a modern Islamic school with all its facilities. Assalam Islamic Modern Boarding School is considered as the best Islamic school in Central Java. Ideologically, this school accepts all groups.

\section{Pondok Pesantren Al-Mukmin Ngruki}

This boarding school was chosen because it was often framed by the mainstream media as a printer for radicalism alumni, besides, Al-Mukmin Islamic boarding school is also in the list of nineteen Islamic boarding schools exposed to radicalism by BNPT. This research is in the form of interpretive qualitative research. The reason for using qualitative research is that it started based on the ontology philosophical assumptions of the nature of reality, drawn in the context of this research, the reality of deradicalization is subjective and plural. Epistemology researchers know what is known and the relationship between researchers and things being studied, in this study, researchers approached the research subjects by visiting the schools which became the objects of research and interacting with research subjects.

From these assumptions and paradigms, qualitative research is carried out when the researcher wants to understand or interpret the context in which the researcher is studying the problems being examined (Creswell, 2007, p. 40). In the context of this research, the formulation of the problems are: (1) How do researchers understand or interpret the views of kiai/ustadz (Muslim scholar) in the spread of radicalism in Islamic boarding schools? (2) How do researchers understand or interpret the efforts of deradicalization by kiai/ustadz in Islamic boarding schools?

The approach used in this study was a case study, as formulated by Yin (2008; 1), case study is a method that refers to research that has elements of how and why on the main questions of his research and examines contemporary (current) problems and the least chance of researchers in controlling event (the 
case) being studied. As a research strategy, it is used in many situations to contribute to our knowledge from individuals, groups, organizations, social, political and all related phenomena. The informants in this study come from the Al-Muayyad Islamic boarding school, Assalam Islamic Modern Islamic Boarding School and residents around the school. The following is a list of the names of informants along with the background of the institutions and the reasons for choosing it.

Tabel 1. List of Informant

\begin{tabular}{|l|l|}
\hline \multicolumn{1}{|c|}{ Name of Informant } & \multicolumn{1}{c|}{ Background of Informant } \\
\hline Anas & Sekretaris ikatan Alumni Al-Mukmin \\
\hline Dian Nafi & Leader of Al-Muayyad Islamic Boarding School \\
\hline Qomarudin & Public Realation of Assalam Modern Islamic Boarding School \\
\hline
\end{tabular}

\section{Results and Discussion}

Based on the data collected from informants through in-depth interviews, this current study found that each boarding school employed its communication strategy as an effort to decrease the amount of radicalism (deradicalize) the institution. The way the informants see radicalism differs between AlMuayyad, Assalam and Al-mukmin. So that the messages conveyed to reduce radicalism also differ between Al-Muayyad, Al-mukmin and Assalam Islamic boarding schools. The Al Muayad Islamic boarding school, represented by KH. Dian Nafi conveyed the messages of deradicalization to AlMuayyad which can also be used by other institutions, especially the Islamic schools that have great potential to produce Islamic discourse as well as moderate movements, for the benefit of the nation. The key is communication between leaders, between schools (institutions) and the spirit of maintaining unity in this country.

The Assalam boarding school, which was represented by Ustadz Qomaruddin, the Head of Public Relations, conveyed the messages of deradicalization which is the Islamic boarding school should design a curriculum from Islamic boarding schools and combined with government (national) curriculum, as well as a curriculum arranged by the boarding schools. He assured that there are no lessons that teach the students to commit violence or even radicalism. Besides, the community in the surrounding of the schools mentioned several efforts to deradicalization such as producing more works, writing moderate ideas about Islamic understanding and publishing the writings in various media.

Whereas, the Al-Mukmin, represented by the secretary of Al-Mukmin Ngruki Alumni association, explained that the radicalism is the same as the term of Ghullu (self-won). Then, to overcome the problem we should have more discussions with persons or groups who are considered as "ghullu" and consider several information sources, do not rely only on one book but compare several media/books which talk about the issue. Do not trust mainstream media and social media too quickly. Check the information from several media or accounts before concluding an issue.

\section{Conclusions}

As it has been clearly stated since the beginning in the results of the study, this current study aims at examining the efforts that have been made to decrease radicalism (deradicalization) through communication building amongst Islamic boarding schools in Solo Raya. So the conclusions of this study can be investigated from 3 points of view. 1). From the perspective of Al-Muayyad, the representative conveyed the messages of deradicalization to Al-Muayyad which can also be used by other institutions, especially the Islamic schools that have great potential to produce Islamic discourse as well as moderate 
movements, for the benefit of the nation. The key is communication between leaders, between schools and the spirit of maintaining unity in this country. 2). From the perspective of Assalam, Islamic boarding schools should design a curriculum from Islamic boarding schools and combined it with a government curriculum, as well as a curriculum arranged by the boarding schools. He assured that there are no lessons that teach the students to commit violence or even radicalism. Additionally, the community in the surrounding of the schools mentioned several efforts to deradicalization such as producing more extensive works, writing moderate ideas about Islamic understanding and publishing the writings in various media. 3). Whereas, from Al-Mukmin perspective, to overcome the problem we should have more discussions with persons or groups who are considered as "ghullu" and consider several information sources, do not rely only on one book, we need to compare several media which talk about the issue. Do not trust mainstream media and social media too quickly. Check the information from several media or accounts before concluding an issue.

\section{References}

Ahmad, Hafal (2017).Youth De-Radicalization:A Canadian Framework.DOAJ:Journal for Deradizalization. Fall 2017 Nr 12 Sept.

Ahyar, Muzayyin (2015). Membaca Gerakan Islam Radikal dan Deradikalisasi Gerakan Islam.Walisongo: Jurnal Penelitian Sosial Keagamaan Vol. 23 No. 1 Mei.

Creswell, John W. (2007). Qualitative Inquiry and Research Design Choosing Among Five Approaches. California: Sage Publication.

Collinsdictionary.com.Definition of Deradicalization.Diakses 23 Januari 2018 dari https://collinsdictionary.com/dictionary/english/deradicalization.

Littlejohn, K. A. (2011). Theories of Humans Communication, tent edition. Long Grove Illinois: Waveland Press, inc.

Miles, Matthew B, A Michael Huberman and Johnny Saldana. (2014). Qualitative Data Analysis: A Methods Sourcebook. Third edition. United State of America : Sage Publication.

Turow, Joseph. (2009). Media Today: an introduction to mass communication. Third edtition. New York: Routledge.

Yin, Robert K. (2003). Case study research : design and methods. California: Sage Publication.

\section{Copyrights}

Copyright for this article is retained by the author(s), with first publication rights granted to the journal. This is an open-access article distributed under the terms and conditions of the Creative Commons Attribution license (http://creativecommons.org/licenses/by/4.0/). 